
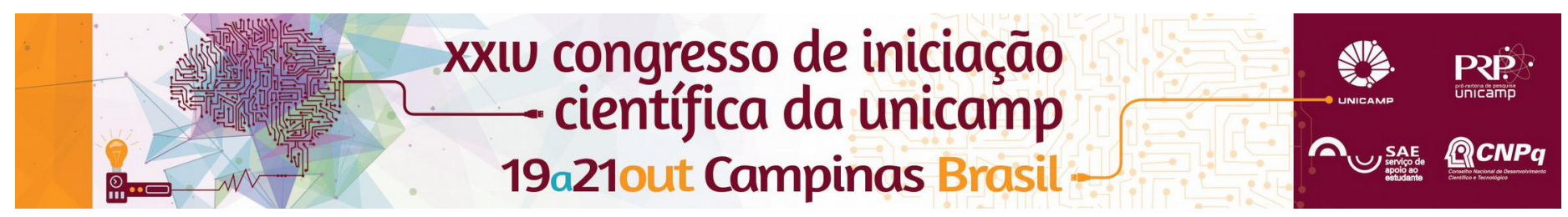

\title{
Os bebes no coletivo da creche: entre o cuidar e educar
}

\section{Ana Selma dos Santos Laurindo}

\section{Resumo}

O objetivo deste trabalho é problematizar a construção de pedagogias nos berçários. Trata-se de um estudo de caso, que contou com a realização de observação durante o período de dois anos em uma creche da região metropolitana de Campinas. Os aportes teóricos que fundamentam a pesquisa tem como pressupostos a sociologia da infância e a pedagogia da infância. Com base nos dados podemos apontam a necessidade de diferentes linguagens para 0 trabalho com bebês, entre elas a arte.

\section{Palavras-chave:}

Bebes, Creche, Educação infantil.

\section{Introdução}

A concepção da educação infantil baseada no binômio cuidado e educação, ora pendendo para um polo, ora para outro do binômio, acompanha o desenvolvimento das instituições de atendimento á infância no Brasil.

Dentro deste quadro as crianças de 0 a 3 anos, nos coletivos das creches, desafiam os modelos canônicos da educação básica, a partir desse pressuposto o presente trabalho tem como o objetivo problematizar a construção de pedagogias nos berçários.

Trata-se de um estudo de caso, que contou com a realização de observação durante o período de dois anos em uma creche da região metropolitana de Campinas.

\section{Resultados e Discussão}

Para isso é preciso aprender a ler as relações entre sujeitos na sua fugacidade e entender que os elementos observáveis permitem apenas inferir a presença de um processo que se caracteriza pela transformação de um modo de funcionamento em outro.

Se no início do século XX considerava-se que bastava ser mulher para lidar com as crianças, hoje, é importante explicitar que para ser educador infantil não basta saber sobre a criança e seu desenvolvimento, é preciso aprender a olhar para a criança, a ouvir a criança, a estar disponível para ela, a brincar com ela e a aprender com ela. Isso acontece porque, como aponta Pino (op. cit), verificar a existência de um processo não é, simplesmente, mostrar os fatos que fazem parte dele, mas reunir indícios que nos permitam seguir o curso dos acontecimentos para apreender e acompanhar as transformações que se operam nesse processo e dele participarmos como adultos.

Quando trabalhamos com bebês precisamos estar aptas a compreender suas diferentes linguagens: precisamos estar atentas aos olhares, aos resmungos, aos choros, aos sorrisos. E precisamos estar atentas aos modos como participamos da relação com eles, ao que com eles compartilhamos.

Ser professora e não dar aula significa oferecer a estas crianças o humano, nas suas possibilidades. Para isso faz-se necessário, descer do salto, sentar no chão e nos permitirmos estar com as crianças, brincar com elas, falar com e para elas, cantar, ouvi-las, significar seus gestos e expressões, rabiscar, pintar, vestir máscaras, contar histórias, fazer de conta, ensinar-Ihes a manejar talheres, a trocar de roupa, a abotoar o casaco, a calçar o sapatos, a controlar os esfíncteres, a dizer palavras, muitas palavras, a gesticular, a dançar, a ser, com o sorriso, com leveza, com limites, com respeito às regras, com os nãos e os sins que fazem parte do mundo no qual eles ingressam.

\section{Conclusão}

Com base nos dados podemos afirmar a necessidade de desnaturalizar as noções de cuidado e de educar a que nos acostumamos e nos disponibilizarmos à relação interpessoal com os bebês para compreendê-los. Precisamos aprender que nada é tão sofisticado que não possa ser oferecido a eles, pois é exatamente nesse momento que a qualidade, fineza, a sutileza de detalhes tem que ser proporcionada, pois são seres em formação, são pessoas em desenvolvimento afetivo, cognitivo, sensitivo e motor, que dependem do nosso compromisso como educadoras (res) para crescerem dignamente. 